\title{
Prevalence of Black Tooth Stains and Dental Caries in Brazilian Schoolchildren
}

\author{
André GASPARETTO ${ }^{1}$ \\ Carlos Alberto CONRADO ${ }^{1}$ \\ Sandra Mara MACIEL ${ }^{1,2}$ \\ Ernesto Yiokihiro MIYAMOTO ${ }^{1}$ \\ Mariliane CHICARELLI ${ }^{1}$ \\ Régia Luzia ZANATA ${ }^{2}$ \\ ${ }^{1}$ School of Dentistry, State University of Maringá (UEM), Maringá, PR, Brazil \\ ${ }^{2}$ School of Dentistry, University of Northern Paraná (UNOPAR), Londrina, PR, Brazil
}

\begin{abstract}
This study evaluated the correlation between the presence of black extrinsic tooth stains and caries in Brazilian schoolchildren. The target population consisted of 263 children aged 6-12 years. Clinical examinations were performed by four dentists calibrated for the World Health Organization criteria for caries diagnosis. The $\chi^{2}$ test was used to compare the prevalence of caries between groups of children with and without black tooth stains. Spearman's correlation test was used to analyze the relationship between the presence of black stains and caries severity. Black stains were observed in $14.8 \%$ of the children. The number of children with caries-free permanent dentition was not statistically different between groups. The mean DMF-T was $1.46 \pm 1.39$ for children with black stains and $2.42 \pm$ 2.09 for children without black stains. A negative correlation was observed between the presence $(r=-0.16 ; p<0.05)$ and severity $(r=$ $-0.15 ; \mathrm{p}<0.01)$ of black stains and DMF-T.
\end{abstract}

Key Words: black tooth stain, dental caries, tooth stains.

\section{INTRODUCTION}

Tooth discoloration is a frequent dental finding associated with clinical and esthetic problems. It differs in etiology, appearance, composition, location, severity and degree of adherence (1). Basically, there are two types of tooth discolorations: those related to intrinsic factors such as congenital or systemic influence and inherited conditions, or those caused by extrinsic factors, related to metallic or nonmetallic stains (2).

Attraction of materials to the tooth surface plays a critical role in the deposition of extrinsic dental stain. The types of attractive force include electrostatic and van der Waals forces, hydration forces, hydrogen bonds and hydrophobic interactions. However, the mechanisms that determine the adhesion strength are not completely understood (2).

Studies focusing on black extrinsic dental stains are scarce in recent scientific literature. This particular type of pigmentation has been considered to be a spe- cial form of dental plaque that differs from other types because it contains insoluble iron salt and a high content of calcium and phosphate (3-5).

According to Reid et al. (5), the black material is a ferric salt, probably ferric sulfide, formed by the reaction between the hydrogen sulfide produced by bacterial action and iron in the saliva or gingival exudates. Although its origin remains somewhat obscure, an association with chromogenic bacteria such as Actinomyces and Prevotella melaninogenica has been reported (3-7).

Black stains may be clinically diagnosed as pigmented dots, lines with incomplete coalescence of dots or continuous lines $(8,9)$, which rarely go beyond the cervical third and contour the crown around the gingival third, not extending to the proximal areas (5). Koch et al. (10) used the following criteria for the diagnosis of black stains: presence of dark dots forming a linear discoloration parallel to the gingival margin at the smooth surfaces of at least two permanent teeth. 
There is no consensus in the literature as to the prevalence of black tooth stains among age groups. However, the presence of these stains has been associated with low caries risk (8-13). Even though there is a large tendency towards a reduction in caries, data on the prevalence of this disease in children from small cities in developing countries such as Brazil are still scarce. Information as to the chromatic alterations on the teeth of these children and a possible association with caries prevalence is even scarcer.

Thus, the aim of this study was to evaluate the correlation between the presence of black extrinsic tooth stains and caries in Brazilian schoolchildren.

\section{MATERIAL AND METHODS}

The target population consisted of all 263 children (130 male and 133 female) aged 6 to 12 years attending the only public school of Porto Rico, State of Parana, Brazil. Porto Rico is a small city (2600 inhabitants) and has no public water fluoridation.

The study design was approved by the Ethics Committee of the State University of Maringá and by the City Health Department. The goals of the study were explained in detail to the parents or caretakers of the patients who met the inclusion criteria. The patients' caretaker signed an informed consent form.

The clinical examinations were performed by four dentists who had been previously trained and calibrated for the World Health Organization criteria for caries diagnosis (14). The intra- and inter-examiner agreements for dental caries diagnosis were evaluated

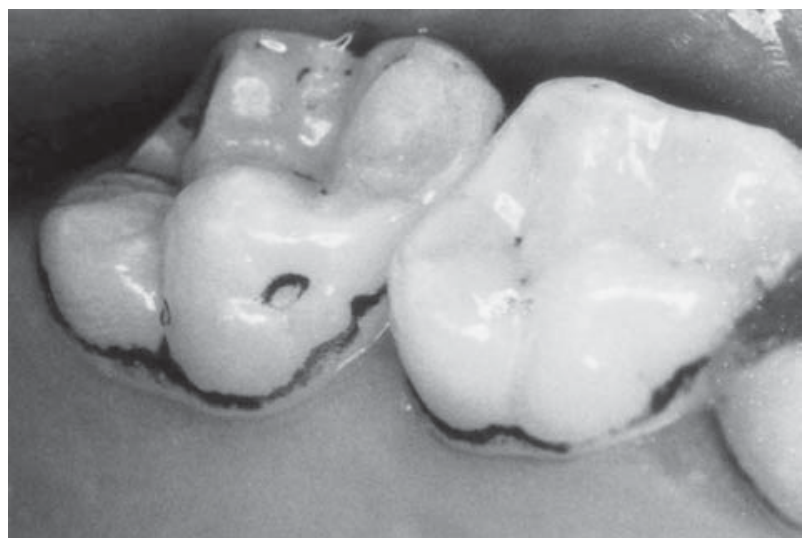

using the kappa test, with kappa values above 0.86 . Clinical examinations were performed under natural light with plane mouth mirrors in the school environment. DMF-T was recorded together with the presence or absence of black stains. Only the permanent dentition was evaluated.

The clinical diagnosis of the black stains was performed according to the criteria of Shourie (8) and Koch et al. (10), and an additional criterion was created for classification based on the extension of the tooth surface area affected by the black stain. Score 1 corresponded to the presence of pigmented dots or thin lines with incomplete coalescence parallel to gingival margin; score 2 corresponded to continuous pigmented lines, which were easily observed and limited to half of the cervical third of the tooth surface; score 3 corresponded to the presence of pigmented stains extending beyond half of the cervical third of the tooth surface (Figure 1).

The caries-free subjects with and without black stains were compared using the $\chi^{2}$ test. The correlation between caries severity and the presence of black stains was analyzed using Spearman's correlation test. Statistical analysis was performed using the Statistical Program of Social Science (SPSS) for Windows. Statistical significance was considered at the $5 \%$ level.

\section{RESULTS}

Black stains were observed in 39 children (19 males and 20 females), $14.8 \%$ of the sample. From the children with black stains, $13(33.3 \%)$ had no caries in

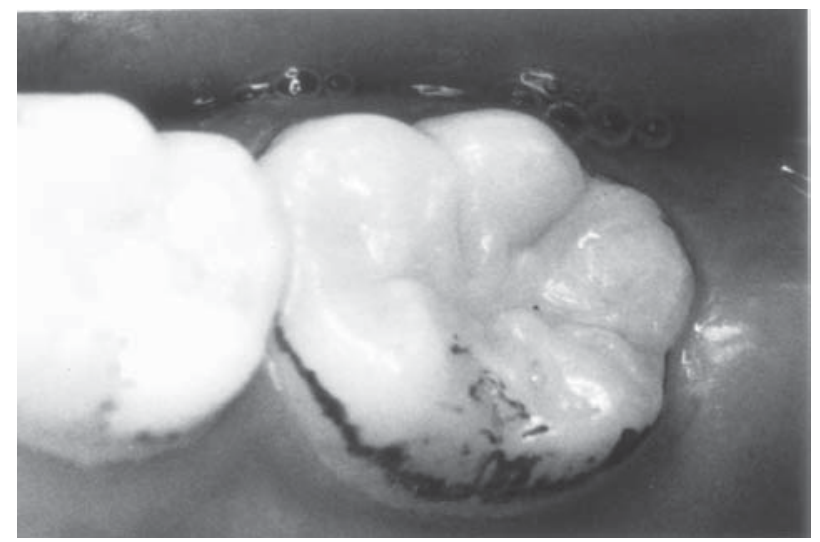

Figure 1. Clinical aspect of black tooth stains. Left panel: score 2 (continuous pigmented lines, which were easily observed and limited to half of the cervical third of the tooth surface). Right panel: score 3 (presence of pigmented stains extending beyond half of the cervical third of the tooth surface). 
the permanent dentition. From the children without black stains, $61(27.2 \%)$ had no caries (Table 1$)$. The number of children with caries-free permanent dentition was not statistically different between groups. From the total sample, 74 children $(28.1 \%)$ were caries-free.

Among the children with black extrinsic stains $(\mathrm{N}=39)$, it was observed that the highest percentage (41\%) was classified as score $3(\mathrm{~N}=16)$, followed by $30.8 \%$ for score $2(\mathrm{~N}=12)$ and $28.2 \%$ for score 1 $(\mathrm{N}=11)$.

The mean DMF-T was $1.46 \pm 1.39$ for children with black stains and $2.42 \pm 2.09$ for children without black stains. The DMF-T for the entire sample was 2.27 \pm 2.03 . Statistical analysis (Spearman's correlation test) showed that the presence of black extrinsic tooth stains was negatively correlated to the severity of caries ( $\mathrm{r}=$ $-0.16 ; \mathrm{p}<0.05)$. In addition, a significant negative correlation between the severity of the black stains (scores) and DMF-T $(\mathrm{r}=-0.16 ; \mathrm{p}<0.01)$ was observed. The DMF-T data are reported in Table 2.

\section{DISCUSSION}

The prevalence and severity of caries in childhood has been decreasing worldwide $(15,16)$. In Brazil,

Table 1 - Prevalence of black extrinsic tooth stains and dental caries.

\begin{tabular}{lrrr}
\hline & With stains & Without stains & Total \\
\hline Caries-free & $13(33.3 \%)$ & $61(27.2 \%)$ & $74(28.1 \%)$ \\
With caries & $26(66.7 \%)$ & $163(72.8 \%)$ & $189(71.9 \%)$ \\
\hline
\end{tabular}

Data are reported as number (percent).

Table 2. DMF-T index distribution of children with and without black extrinsic tooth stains $(\mathrm{N}=263)$.

\begin{tabular}{lccccccc}
\hline Children & \multicolumn{7}{c}{ DMF-T } \\
\cline { 2 - 8 } & 0 & 1 & 2 & 3 & 4 & 5 & $6-8$ \\
\hline $\begin{array}{l}\text { Without stains } \\
(\mathrm{n}=224)\end{array}$ & 61 & 24 & 33 & 36 & 42 & 9 & 19 \\
& $(27.2 \%)$ & $(10.7 \%)$ & $(14.7 \%)$ & $(16.1 \%)$ & $(18.8 \%)$ & $(4.0 \%)$ & $(8.5 \%)$ \\
$\begin{array}{l}\text { With stains } \\
(\mathrm{n}=39)\end{array}$ & 13 & 8 & 10 & 4 & 3 & 1 & 0 \\
\hline
\end{tabular}

this decrease has been highlighted in national surveys carried out in the 1980s and 1990s $(17,18)$. The last national survey revealed a mean DMF-T of 3.1 and a prevalence of $75 \%$ at 12 years of age. However, this study was conducted only in State capitals, and there are doubts as to whether the same pattern of disease would be observed in small cities at the interior of the country. According to the State Health Service of Paraná (19), eighty-six municipalities of the State have a mean DMF-T $\geq 6$ at 12 years of age.

The present study was conducted in a small city based on a rural economy with no fluoridation of the public water supply. A mean DMF-T of $2.27( \pm 2.03)$ was observed for the age range evaluated. This value is higher than the mean values found on the last national survey for the same age range, which were 1.57 for the country as a whole and 1.14 for the State of Paraná (18).

A caries prevalence of $72 \%$ of the permanent dentition of such a young population and a DMF-T value above the mean for the country and state highlight the need for measures to control the disease in the study population.

Most of the studies conducted on black stains occurred during the 1960s and 1970s. Nevertheless, scientific evidence has demonstrated some relevant aspects on this issue. Sutcliffe (20) reported a prevalence of $21 \%$ of black stains in a population of nearly one thousand children aged 11 to 13 years. According to Koch et al. (10), a prevalence of $19.9 \%$ has been reported for school children from Switzerland (aged 715 years), and a prevalence of $4.6 \%$ was observed in schoolchildren aged six to ten years of age in Germany. Brazilian studies report a prevalence of $9.3 \%$ of black stains for children aged 6 to 13 years (12) and $2.5 \%$ for children aged 3 to 5 years (9), from different areas of the country. Koch et al. (10), in Italy, observed a $6.3 \%$ prevalence of black stains in a population of the same age range as the present study; however, they reported a lower mean DMF-T.

Several studies $(8-13,20)$ demonstrated lower caries experience for children with black stains. These data are in agreement with the outcome of the present study. However, the mechanism of biological interaction between the mi- 
crobiota related to the extrinsic pigmentation and the cariogenic microbiota is not completely understood.

The morphologic studies of black stains reported by Theilade et al. (3) and Reid et al. (5) confirmed that this kind of stain is a special type of dental plaque characterized by its flora and its tendency to calcify. According to Reid and Beeley (4) and Slots (6), the predominant organisms in black stains are Actinomyces and Prevotella melaninogenicus. The tendency towards calcification within the black material promotes a high level of calcium and phosphate that contributes to a reduction in the enamel dissolution and an increase in the buffering capacity.

Surdacka (11) assessed the chemical composition of the saliva in children aged 4-16 years with black stains on the teeth, and in children in the same age range without black stains (control). The saliva of the former demonstrated a significantly higher content of total calcium, inorganic phosphates, copper, sodium and total protein and less glucose than in controls. This chemical composition is characteristic of subjects with low susceptibility to caries.

The reason why some individuals accumulate a compound whereas others do not is not clear. However, according to Reid and Beeley (4), the phenomenon may be attributed to differences in plaque microbiota or its metabolism, or to the composition of the saliva or gingival fluid.

According to Koch et al. (10), the microbiota of black stain might be an interesting model of replacement of oral pathogens and further studies in populations of different age ranges evaluating the hypothesis that black stains are protective against caries would seem justified.

In the present study, the prevalence of black tooth stains and caries were not significantly different between males and females. None of the patients with black stains were using mouth rinses or were taking any ferrous sulfate supplement.

The present study did not find any statistical difference between the presence of black stains and the caries prevalence. However, a significant correlation was found between the presence of black stains and the severity of the disease, as evaluated by means of the DMF-T index. A DMF-T $>3$ was seen for $10.3 \%$ of the children "with stains" and $31.3 \%$ of the children "without stains". No child with black stains presented DMF$\mathrm{T}$ above 5, whereas this condition was observed in $8.5 \%$ of the children "without stains".

Another interesting finding was that the amount or extension of staining was significantly correlated to DMF-T, i.e., less caries were observed among those children with the largest areas affected by the stains (score 3).

For the population and conditions of this study, a negative correlation was observed between the presence of black stains and caries severity in the permanent dentition.

\section{RESUMO}

O presente estudo avaliou a correlação entre a presença de manchas extrínsecas pretas no esmalte dental e experiência de cárie de escolares brasileiros. A população alvo consistiu de 263 crianças com idades entre 6 e 12 anos. Os exames clínicos foram realizados por quatro dentistas calibrados de acordo com o critério da Organização Mundial de Saúde para diagnóstico de cárie. $O$ teste $\chi^{2}$ foi usado para comparar a prevalência de cárie entre crianças com e sem manchas pretas no esmalte. $O$ teste de correlação de Spearman foi usado para analisar a relação entre a presença de mancha preta e a severidade da doença cárie. A presença de manchas pretas foi diagnosticada em 14,8 por cento das crianças. O número de crianças livre de cárie na dentição permanente não foi estatisticamente diferente entre os grupos. $\mathrm{O}$ CPO-D médio foi $1,46 \pm 1,39$ para crianças com manchas pretas e 2,42 $\pm 2,09$ para crianças sem mancha. Observou-se correlação negativa entre a presença $(r=-0,16 ; p<0,05)$ e severidade $(r=$ $-0,15 ; \mathrm{p}<0,01)$ da mancha preta e o CPO-D.

\section{REFERENCES}

1. Hattab FN, Qudeimat MA, Al-Rimawi HS. Dental discoloration: an overview. J Esthet Dent 1999;11:291-310.

2. Nathoo SA. The chemistry and mechanisms of extrinsic and intrinsic discoloration. J Am Dent Assoc 1997;128:6S-10S.

3. Theilade J, Slots J, Fejerskov O. The ultrastructure of black stain on human primary teeth. Scand J Dent Res 1973;81:528-532.

4. Reid JS, Beeley JA. Biochemical studies on the composition of gingival debris from children with black extrinsic tooth stain. Caries Res 1976;10:363-369.

5. Reid JS, Beeley JA, MacDonald DG. Investigations into black extrinsic tooth stain. J Dent Res 1977;56:895-899.

6. Slots J. The microflora of black stain on human primary teeth. Scand J Dent Res 1974;82:484-490.

7. Coury E, Bandeira SMM. Manchas dentárias extrínsecas pretas: revisão de literatura. ROBRAC 1998;7:26-27 [article in Portuguese].

8. Shourie KL. Mesenteric line or pigmented plaque: a sign of comparative freedom from caries. J Am Dent Assoc 1947;35:805807.

9. Franco KD, Issao M. Manchas extrínsecas e sua relação com prevalência de cárie. Rev Paul Odontol 1990;12:23-30 [article in Portuguese]. 
10 Koch MJ, Bove M, Schroff J, Perlea P, Garcia-Godoy F, Staehle H. Black stain and dental caries in schoolchildren in Potenza, Italy. J Dent Child 2001;68:353-355.

11. Surdacka A. Chemical composition of the saliva in children and adolescents with black tartar. Czas Stomatol 1989;42:525-533 [article in Polish].

12. Bastos VAS, Galan Jr J. Estudo das manchas extrínsecas negras e marrons e sua relação com as cáries dentárias. Rev Bras Odontol 1992;49:2-6 [article in Portuguese].

13. Costa SC, Imparato JCP, Franco AEA, Camargo MCF. Estudo da ocorrência de manchas extrínsecas negras em crianças e sua relação ao baixo índice de cárie dental. Rev Facul Odontol Santo Amaro 1997;2:36-38 [article in Portuguese].

14. World Health Organization. Oral Health Surveys. Basic Methods. Geneva: WHO. 1997.
15. Bonecker M, Cleaton-Jones P. Trends in dental caries in Latin American and Caribbean 5-6 and 11-13-year-old children: a systematic review. Community Dent Oral Epidemiol 2003;31:152157.

16. Peterson $\mathrm{HG}$, Bratthall $\mathrm{D}$. The caries decline: a review of reviews. Eur J Oral Sci 1996;104:436-443.

17. Ministério da Saúde. Levantamento Epidemiológico em Saúde Bucal (Primeira etapa-cárie dental). Coordenação de Saude Bucal. 1988 [article in Portuguese].

18. Ministério da Saúde. Levantamento Epidemiológico em Saúde Bucal (Primeira etapa-cárie dental). Coordenação de Saude Bucal. 1998 [article in Portuguese].

19. www.saude.pr.gov.br:2080/Bucal.nsf/

20. Sutcliffe P. Extrinsic tooth stains in children. Dental Practice $1967 ; 17: 175-179$

Accepted August 29, 2003 